\title{
SULAM MOTIF FLORA DAN FAUNA DITINJAU DARI WARNA DAN KOMPOSISI
}

\author{
Aisyah Ratna Dewi ${ }^{1 *}$, Heri Soeprayogi ${ }^{2 *}$, Sri Wiratma $^{3 *}$ \\ Program Studi Pendidikan Seni Rupa Jurusan Seni Rupa Fakultas Bahasa dan Seni \\ Universitas Negeri Medan \\ Jl. Willem Iskandar Pasar V Medan Estate, Kec, Percut Sei Tuan, Kab. Deli Serdang, Kode Pos 20371 \\ Sumatera Utara. Indonesia \\ Email: aisyahratna201999@gmail.com
}

\begin{abstract}
Abstrak
Penelitian ini bertujuan untuk mengetahui ketepatan siswa dalam memilih warna dan komposisi yang sesuai pada karya sulam teknik sulam bebas dengan motif flora dan fauna. Adapun populasi yang digunakan dalam penelitian ini adalah seluruh siswa kelas VIII-7 SMP Negeri 16 Medan dengan sampel 3 karya siswa dengan teknik Cluster Random Sampling. Metode penelitian yang digunakan adalah deskriptif kualitatif dengan mendeskripsikan karya sulam yang diteliti dan dinilai berdasarkan unsur seni rupa yang telah ditentukan yaitu warna dan komposisi. Secara keseluruhan kemampuan siswa SMP Negeri 16 medan dalam praktik menyulam dikatakan Cukup Baik. Siswa sudah memiliki kemampuan dalam menyatukan motif-motif yang akan disulam dan hasil sulamnya pun rata-rata sudah mendekati kategori cukup.
\end{abstract}

Kata Kunci: sulam, warna, komposisi.

\begin{abstract}
This study aims to determine the accuracy of students in choosing the right color and composition in the embroidery work of free embroidery work of free embroidery techniques with flora and fauna motifs. As for the population used in this study were all students of class VIII-7 junior high school 16 terrain with a sample of 3 students' work using a random sampling technique. The research method used is descriptive qualitative by describing the work of embroidery that is examined and assessed based on predetermined fine art elements, namely color and composition. As a whole the ability of 16 field students in the field of embroidery is said to be quite good. Students already have the ability to unify the motif to be embroidered and results of embroidery are on average already close to the sufficient category.
\end{abstract}

Keywords: embroidery, color, composition.

\section{PENDAHULUAN}

Mata pelajaran seni budaya merupakan mata pelajaran yang wajib ditempuh di SMP Negeri 16 Medan. Kerajinan menyulam diberikan dengan tujuan agar siswa memiliki kecakapan dan keterampilan dalam menerapkan motif flora dan fauna dengan menghias benda menggunakan tekhnik sulam bebas, sehingga siswa dapat menghasilkan karya-karya sulaman yang berkualitas.

Berdasarkan observasi, peneliti mengamati secara langsung bahwa minat dan motivasi siswa di dalam kelas masih kurang, hal ini dapat dilihat dari sisi minat siswa laki-laki lebih cenderung kurang antusias untuk mengikuti pelajaran seni budaya dibandingkan dengan siswi perempuan khususnya pada materi pelajaran menyulam, hal tersebut terjadi karena didalam pola pikir mereka telah tertanam bahwa menyulam adalah pekerjaan khusus perempuan, karena dalam keterampilan menyulam sangat dibutuhkan kesabaran, ketelitian, dan ketekunan dalam mengerjakannya, dan hanya kaum perempuan saja lah yang pantas untuk mengerjakan pekerjaan tersebut. Selain itu timbul juga permasalahan lain seperti kurangnya pemahaman tentang pengetahuan menyulam sehingga terkesan monoton, dari beberapa uraian dan hasil pengalaman di lapangan dapat diketahui bahwa dalam praktek menyulam tidak dilakukan secara individu melainkan secara berkelompok, sehingga hanya beberapa orang siswa saja yang aktif dalam kegiatan praktek menyulam dan sebagian dari siswa tersebut menjadi cenderung pasif bahkan tidak perduli sama sekali. Kemudian pada saat pemilihan motif, Motif yang biasa digunakan disekolah lebih cenderung menggunakan motif flora dan dibuat dengan teknik tusuk silang. Penggunaan teknik tusuk silang seperti ini sejatinya mudah untuk diterapkan pada pola seperti flora yang dapat menggunakan pola dasar geometris, namun tidak halnya dengan motif fauna. Bentuk dari hewan tertentu saja didasari dengan pola dasar yang bersifat Asimetris, 


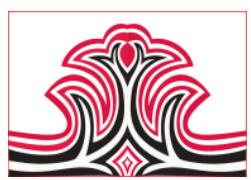

sehingga siswa merasa kesulitan dan lebih memilih pola flora dibandingkan fauna untuk dibuat menjadi sebuah karya sulam.

Masalah yang timbul selanjutnya ialah dalam aspek pemilihan warna dan komposisi pada karya sulam, siswa lebih cenderung menggunakan warna-warna dasar seperti warna hijau muda dan merah, warna hijau dimanfaatkan sebagai warna pada daun dan warna merah sebagai bunganya. Kemudian dalam komposisi penempatan tata letak, siswa siswi hanya memenuhi motif di bagian satu sisi saja sehingga sisi lainnya terlihat kosong.

Pada pembelajaran praktek peserta didik diharapkan dapat mengaplikasikan beberapa gabungan tekhnik menyulam dengan menggunakan variasi teknik tusukan. Hal ini dilakukan untuk melihat apakah siswa dapat membuat karya sulaman dengan menggunakan motif flora dan fauna secara lebih kreatif dan lebih bersemangat dalam menyulam. Pada proses menyulam peserta didik di tuntut untuk dapat mengembangkan kemampuan dan kreatifitasnya seperti dalam pemilihan warna, motif, dan komposisi, untuk menciptakan sebuah hasil karya sulam yang berkualitas.

\section{KAJIAN TEORI}

\section{Pengertian Analisis}

Spradly (dalam Sugiyono 2008:335) mengatakan: "Analisis dalam penelitian jenis apapun adalah merupakan cara berfikir. Hal ini berkaitan dengan pengujian secara sistematis terhadap sesuatu untuk menentukan bagian dan hubungannya dengan keseluruhan. jadi analisis adalah untuk mencari pola”.

Selanjutnya Menurut Sugito (2017:76) dalam Buku Metode Penelitian Pendidikan Seni Rupa, dijelaskan bahwa:" Penelitian identik dengan data, oleh sebab itu ketepatan memilih teknik analisis data menjadi sangat penting. Teknik analisis data terbagi atas dua macam yaitu analisis non statistik dan analisis statistik, pemilihan tekniknya tergantung pada rumusan masalah dan jenis data yang dikumpulkan apakah data non statistik dilakukan terhadap data tidak berbentuk angka (kualitatif), sedangkan analisis statistik dilakukan terhadap data yang berbentuk angka (kuantitatif)".

\section{Pengertian Sulam}

Menurut Budiyono (2008:177)“Istilah sulam identik dengan bordir karena bordir diambil dari istilah dalam bahas inggris embroidery (im-broide) yang artinya sulaman".Ditinjau dari sejarah, pengerjaan kerajinan hias tersebut sangat sederhana, berawal hanya dengan jarum dan benang, dengan menggunakan jari jemari
Gorga : Jurnal Seni Rupa

Volume 09 Nomor 01 Januari-Juni 2020

p-ISSN: 2301-5942 | e-ISSN: 2580-2380

tangan, kedua alat tersebut ditusuk-tusukan pada kain, lalu munculah berbagai istilah tusuk-tusuk hias (setik).

Pada akhirnya kegiatan tersebut disebut dengan istilah sulam dan bordir. Sementara menurut Kamus KBBI (2008:1385) pengertian sulaman disamakan dengan bordir, suji, dan tekat, yaitu hiasan dari benang yang dijahitkan pada kain. Dengan berkembangnya teknologi, pengerjaan bordir dilakukan dengan memakai alat berupa mesin jahit atau mesin bordir khusus (high speed), sehingga hasil pengerjaannya lebih baik dan cepat.

\section{Jenis Sulam}

Menurut Ernawati (2008:408) jenis-jenis sulam terdiri dari 7 jenis yaitu: sulaman fantasi sering disebut dengan sulaman bebas karena karena sulaman ini didesain dengan memvariasikan tusuk hias dan warna benang pada bahan tenunan polos, sulaman hongkong yaitu sulaman yang dijahit dengan variasi tusuk pipih yang dijahitkan mengisi seluruh permukaan motif, sulaman aplikasi merupakan salah satu sulaman dengan teknik lekapan yang ragam hiasnya dibentuk dari bahan lain kemudian ditempelkan pada permukaan kain, sulaman kruistik sulaman ini dikenal dengan sulaman tusuk silang, sulaman melekatkan benang yaitu sulaman yang motifnya dibentuk dari benang sulam yang kasar ditempelkan secara terus menerus tidak terputus-putus, terawang hardanger yaitu ragam hias yang dibentuk dari ragam lobang-lobang berbentuk geometris, terawang imggris yaitu ragam hias yang dibentuk dari ragam yang mempunyai lobang-lobang berbentuk geometris bundaran-bundaran atau bentuk oval yang terjadi karena kainnya ditoreh atau digunting.

\section{Motif Flora dan Fauna}

Menurut (Suhersono 2005:13) "motif merupakan desain atau rancangan yang dibuat dari bagian-bagian bentuk, berbagai macam garis yang dipengaruhi dalam bentuk stilasi atau penggayaan, dan memiliki ciri tersendiri. Setiap motif dibuat dengan berbagai bentuk dasar atau berbagai macam garis, misalnya berbagai bentuk segitiga, segi empat, segi lima, garis ikal atau spiral, melingkar, berkelok-kelok". Sedangkan Fauna berasal dari Bahasa latin atau alam hewan artinya adalah Khazanah segala macam jenis hewan yang hidup di bagian tertentu atau priode tertentu.

Dari beberapa pendapat di atas dapat disimpulkan bahwa motif Flora dan Fauna merupakan dua objek yang sering digunakan dalam setiap pembuatan produk-produk karya seni seperti batik, tenun, dan sulam. 


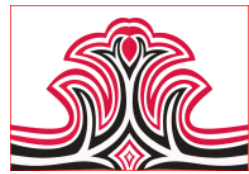

5. Unsur-unsur Desain

1). Garis

Garis adalah kumpulan dari titik-titik yang bersambung. Menurut Irawan (2013:10) "Garis adalah unsur rupa yang paling utama. Ini disebabkan apabila kita ingin menggambar ataupun mendesain, wujud yang pertama kali ditorehkan adalah garis". Sedangkan menurut Ching (2002:36) menjelaskan "Garis adalah sebuah konvensi garis yang kita terima karena kita melihat kontur sebagai garis-garis kontras".

\section{2). Bentuk}

Bentuk merupakan garis-garis yang membentuk bagian dasar. Peran garis secara alami sangat luas dari sekedar mendeskripsikan bentuk dalam bidang visual. Dengan adanya bentuk itulah kita mengapresiasikan bentukbentuk dunia visual kita. Mesra dalam Siregar (2020: 95) mengungkapkan bahwa bentuk dilihat dari sisi menggambarnya yakni suatu proses memindahkan bentuk objek ke atas bidang datang atau dua dimensional dengan cara menggoreskan benda yang menimbulkan kesan atau tanda berupa garis.

Menurut Ching (2002:59) menyatakan pengertian bentuk sebagai berikut: "Bentuk adalah konsep dua dimensi dari suatu benda yang berada didalam batasbatasnya sendiri dan terpisah dari bidang visual yang lebih besar. Jadi bentuk tergantung pada garis yang mendeskripsikan batas-batasnya atau kontras dari nada gelap-terang, warna, atau tekstur yang terjadi sepanjang batas-batas tersebut".

\section{3). Bidang}

Menurut Sembiring (2014:41) bidang (Shape) adalah suatu bentuk yang sekelilingnya dibatasi oleh garis. Secara umum dikenal dua jenis bidang yaitu bidang geometris seperti lingkaran atau bulatan, segi empat, segi tiga dan segi-segi lainnya, sementara bidang dengan bentuk bebas terdiri dari aneka macam bentuk yang tidak terbatas. Sedangkan menurut Irawan (2013:23) bidang adalah beberapa garis yang berbeda arah dan saling berpotongan akan membentuk pola (pattern).

Dari pengertian tersebut dapat disimpulkan bahwa bidang adalah bentuk yang sekelilingnya dibatasi dengan garis, bidang bersifat dua dimensi atau bermatra dua, karena tidak memiliki kedalaman namun bidang memiliki ukuran atau luasan.

\section{4). Tekstur}

Tekstur merupakan tampilan permukaan dari suatu benda yang dapat dinilai dengan cara dilihat atau diraba. Tekstur dapat dilihat dari tebal tipisnya bahan
Gorga : Jurnal Seni Rupa

Volume 09 Nomor 01 Januari-Juni 2020

p-ISSN: 2301-5942 | e-ISSN: 2580-2380

yang digunakan, tebal tipisnya bahan sangat mempengaruhi desain hiasan yang akan dipilih. Menurut Irawan (2013:25) "Struktur adalah susunan bahan pada sebuah bidang". Oleh karena ada struktur bahan maka pada permukaan bahan tersebut akan menimbulkan tekstur.

\section{5). Komposisi}

Menurut Mesra (2014: 83) menjelaskan "Komposisi adalah tata letak objek ditengah-tengah bidang terlihat seimbang atau wajar. Objek tidak terlalu besar jika dibandingkan luasnya bidang". Jadi dapat disimpulkan bahwa Komposisi adalah susunan atau perpaduan dari beberapa objek yang ditata sedemikian rupa sehingga membentuk satu kesatuan yang harmoni”.

\section{6). Warna}

Susanto (2011 : 433) dalam buku Diksi Rupa menyatakan bahwa warna didefinisikan sebagai getaran atau gelombang yang diterima indera penglihatam manusia yang berasal dari pancaran cahaya melalui sebuah benda.

Menurut Nugroho (2008 : 2) dalam buku Pengenalan Teori Warna mendefinisikan "warna itu sendiri adalah spektrum tertentu yang terdapat di dalam suatu cahaya sempurna (berwarna putih). Identitas suatu warna ditentukan panjang gelombang cahaya tersebut".

Dengan demikian dari beberapa defenisi tersebut dapat diambil kesimpulan bahwa warna adalah elemen visual dari hasil pantulan cahaya yang dapat memiliki makna simbolis dan melambangkan suatu tradisi, budaya, adat maupun agama yang ada pada daerah masing-masing.

\section{METODE PENELITIAN}

Peneliti menggunakan metode pendekatan deskriptif kualitatif dengan langkah-langkah sebagai berikut: observasi berperan serta (participan observation), dan dokumentasi. Kualitatif lebih menekankan pada proses pengidentifikasi secara langsung terhadap rya yang diteliti. Deskriptif menggambarkan atau menguraikan data yang telah terkumpul sebagaimana adanya. 


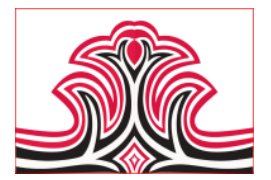

HASIL DAN PEMBAHASAN

\section{Hasil}

\section{1). Karya 1}

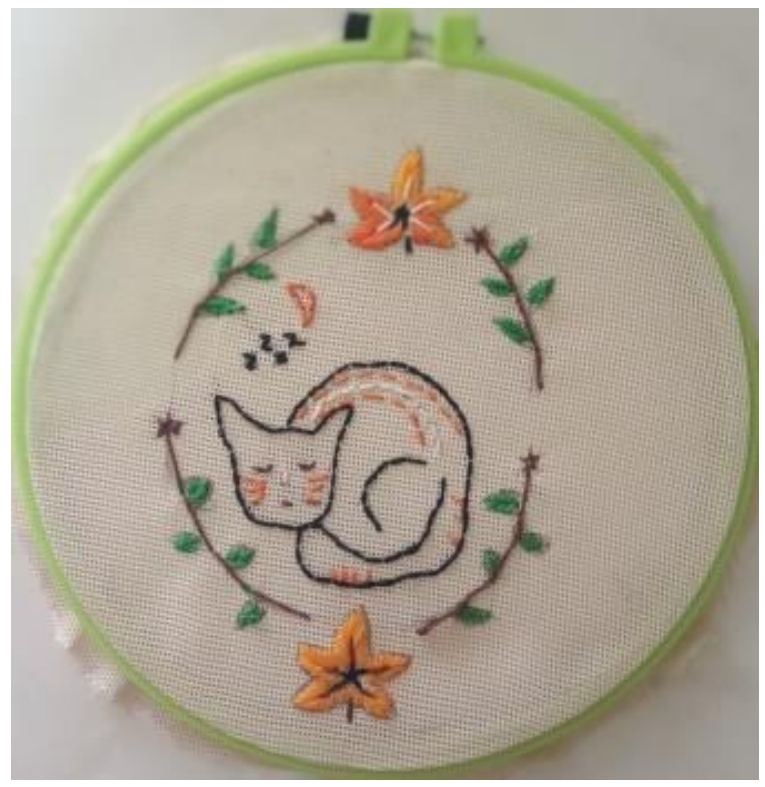

Gambar 1. Karya Aidil Azmi

(Sumber: Aisyah Ratna Dewi, 2019)

Berdasarkan penilai pada indikator warna memperoleh nilai dengan rata-rata 74,66 dalam kategori kurang. Warna pada karya tersebut memiliki warna yang kontras antara warna background kain dengan motif sehingga motif terlihat jelas, Menurut teori warna darmaprawira warna kuning memiliki makna kecerdasan, kebahagiaan, sinar kehidupan, ketulusan, dan kemakmuran. Warna pada motif sulam terlihat sedikit monoton, teori warna yang digunakan adalah teori warna komplementer yaitu warna yang bersebrangan pada lingkaran warna seperti warna hijau dan orange. kemudian pengulangan warna pada motif tidak terlalu banyak karena hanya cenderung menggunakan 3 warna seperti warna hijau, orange, dan warna hitam.

\section{2). Karya 2}

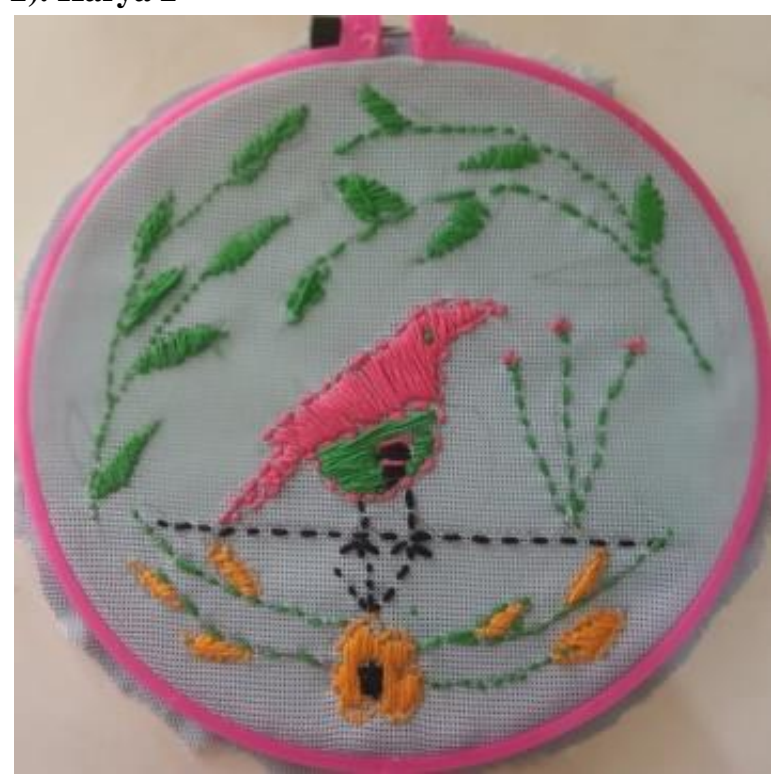

Gambar 2. Dicky Pratama Putra

(Sumber: Aisyah Ratna Dewi, 2019)

Warna merupakan hal yang utama dalam menyulam, elemen dalam warna memiliki peran masing-masing dalam membangun keseluruhan warna yang harmonis. Warna pada karya sulam ini mendapat peroleh nilai rata-rata 75,66 kategori cukup. Berdasarkan penilaian indikator warna, pada karya tersebut menggunakan warna biru sebagai backgroundnya sehingga memiliki warna yang kontras antara warna kain dengan warna motif sehingga terlihat jelas. pengulangan warna tidak terlalu banyak dan lebih dominan menggunakan warna hijau, warna pada motif terkesan datar karena pemilik karya hanya menggunakan warna-warna dasar dan tidak memberikan efek gradasi pada daun maupun objek lainnya, warna motif pada burung kurang sesuai dengan warna objek aslinya. 


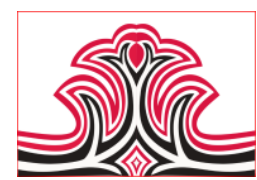

3). Karya 3

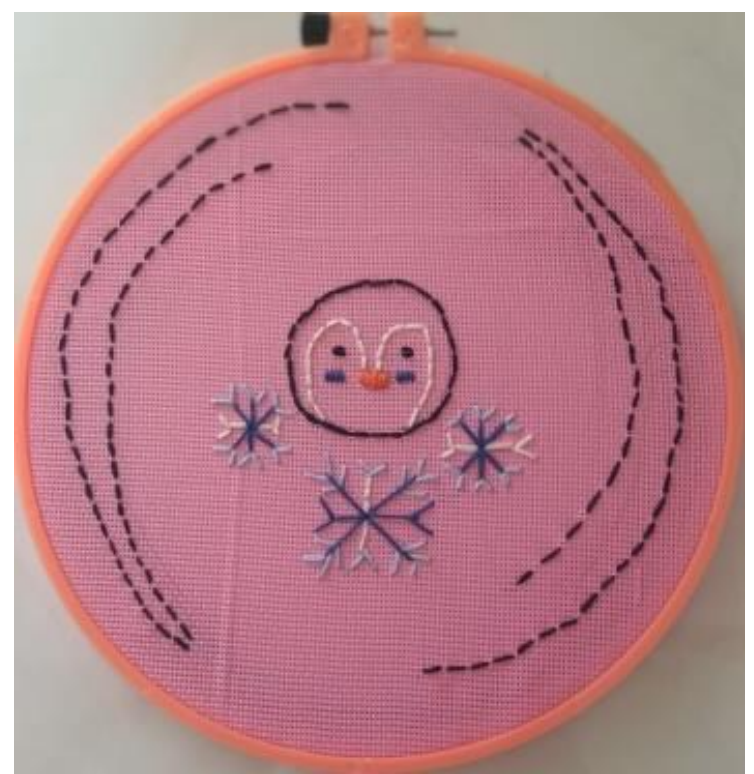

Gambar 3. Djagad Satryo

(Sumber: Aisyah Ratna Dewi, 2019)

Berdasarkan hasil penilaian pada indikator Warna memperoleh nilai dengan rata-rata 71,33 dalam kategori kurang Berdasarkan indikator penilaian warna, pada karya diatas memiliki warna yang serasi antara kain dengan motif sehingga motif terlihat jelas, teori warna yang digunakan adalah teori warna monokromatik yaitu campurn warna-warna dari ketiga variabel dimensi warna yang berasal dari satu warna, kemudian warna pada motif sesuai dengan objek aslinya, pengulangan warna yang digunakan tidak banyak karena hanya menggunakan satu warna yang lebih dominan yaitu warna hitam.

\section{Pembahasan}

Pada karya 1 Indikator komposisi mendapatkan nilai dengan rata-rata 74,66 dalam kategori kurang. Keseimbangan pada karya sulam menggunakan keseimbangan sentral yaitu keseimbangan yang meletakan objek ditengah-tengah dari bidang dimana penempatan objek diatur berdasarkan bentuk objek. ukuran pada motif sulam terlalu kecil sehingga masih banyak bidang kosong pada kain, kemudian bentuk pada motif sulam memiliki karakter sehingga mudah untuk dikenali. Tekstur yang timbul terdapat 2 jenis, karena pada karya sulam hanya menggunakan 2 jenis tusukan saja yaitu tusuk daun dan tusuk tikam jejak.

Pada karya 2 indikator penilaian komposisi mendapat nilai 75,33 termasuk dalam kategori nilai cukup.kemudian pada indikator penilaian komposisi keseimbangan yang digunakan adalah keseimbangan asimetris . ukuran pada motif juga tidak terlalu besar maupun kecil hanya saja bentuk motif masih kurang
Gorga : Jurnal Seni Rupa

Volume 09 Nomor 01 Januari-Juni 2020

p-ISSN: 2301-5942 | e-ISSN: 2580-2380

jelas dan teknik sulam yang digunakan hanya 2 saja yaitu tusuk sattin dan tusuk sulam tikam jejak.

Pada karya 3 indikator penilaian komposisi dengan rata-rata nilai 73,33 berdasarkan indikator penilaian komposisi, keseimbangan yang diganakan adalah keseimbangan simetris hal tersebut dapat terlihat dari motif sulam yang berada ditengah dengan jarak kanan, kiri, atas, dan bawah yang sama sehingga terlihat sejajar, hanya saja motif tidak terlalu banyak jadi pada bagian atas dan bawah masih memiliki ruang yang kosong, ukuran motif tidak terlalu besar maupun kecil, dan bentuk motif jelas hampir menyerupai objek aslinya, tekstur yang dihasilkan sama rata yaitu dengan menggunakan 1 teknik tusuk sulam saja, teknik tusuk sulam yang digunakan adalah tusuk sulam tikam jejak.

\section{KESIMPULAN DAN SARAN \\ 1.Kesimpulan}

Jika dilihat dari hasil analisis pada karya sulam pada ke3 siswa masih kurang, teori warna yang digunakan pada siswa rata-rata menggunakan teori warna komplementer, dalam pemilihan warna motif sulam siswa masih belum berani menggunakan gradasi warna pada karya sulam, namun secara keseluruhan kesatuan warna background dan motif sulam sudah baik, karena terdapat beberapa bagian pada motif sulam yang kontras. Pada indikator komposisi rata-rata sudah cukup baik, siswa sudah mampu menggabungkan motif flora dan fauna, keseimbangan yang digunakan dalam karya siswa rata-rata menggunakan keseimbangan asimetris sehingga terdapat bagian pada karya siswa yang penempatan motifnya tidak beraturan.

\section{Saran}

Bagi guru, dalam belajar seni rupa terkhususnya dalam praktik menyulam, Guru menjelaskan hal-hal yang berkaitan dengan teknik-teknik dalam menyulam sehingga siswa mampu memahami teknik-teknik sulam dan Guru mampu menjelaskan kesalahan-kesalahan siswa dalam menyulam menggunakan teknik sulam bebas. Bagi Siswa, diharapkan siswa harus mengerti teknik apa-apa saja yang digunakan dalam menyulam bebas dan siswa diharapkan harus mengerti dalam menentukan komposisi dan warna-warna yang sesuai dengan motif sulam sehingga karya yang dihasilkan baik.

\section{DAFTAR RUJUKAN}

Budiyono, dkk. (2008). Kriya Tekstil. Jakarta: Direktorat Pembinaan Sekolah Menengah Kejuruan. 
Ching, Francis DK. (2002). Menggambar Sebuah Proses Kreatif. Jakarta: Penerbit Erlangga.

Darmaprawira, Sulasmi. (2002). Warna: Teori dan dasar Kreativitas Penggunaannya. Bandung: Penerbit ITB.

DPN. (2008). Kamus Bahasa Indonesia. Jakarta: Pusat Bahasa.

Ernawati, dkk. (2008). Tata Busana. Jakarta: PT Macanan Jaya Cemerlang.

Irawan, Bambang dan Tamara, Pricilla. (2013). DasarDasar Desain. Jakarta. Griya Kreasi.

Mesra. (2014). Menggambar Bentuk 1. Medan: Unimed Press.

Nugroho, Eko. (2008). Pengenalan Teori Warna. Yogyakarta: Andi.

Sembiring, Dermawan, dkk. (2014). Wawasan Seni. Medan: Unimed Press.

Siregar, N. H., Azis, A. C. K., Mesra, M., \& Mirwa, T. (2020). Analisis Gambar Bentuk Bunga Anggrek dengan Teknik Pointilis Berwarna di SMP AlFityan School Medan. Gorga: Jurnal Seni Rupa, 9(1), 94-99.

Soemantri, Bambang. (2005). Tusuk Sulam Dasar. Yogyakarta: Gramedia Pustaka.

Sugito, dkk. (2016). Metode Penelitian Seni Rupa. Medan: Unimed Press.

Sugiyono, (2017). Metode Penelitian Pendidikan. Bandung: Alfabeta.

Suhersono, Hery. (2005). Desain Bordir Motif Fauna.Jakarta: Gramedia.

Susanto, Mikke. (2011). Diksi Rupa. Yogyakarta: DictiArt Lab \& Jagad Art Space. 